\title{
Switzerland increases control of nuclear power
}

THE referendum on the law governing atomic power in Switzerland last weekend-at which voters approved the government's revision by more than two to one-was hardly the centre of a historic debate. In comparison to the heated debate before the 18 February vote on the nuclear issue - which by a narrow margin upheld the old law rather than one which would have prevented further development of nuclear power-the political temperature has reached an all-time low. All the major parties and organisations either recommended voting for the revision, or refused to take up positions. There has been no propaganda clash. The newspapers are practically void of announcements, and the usual stream of press conferences and meetings is absent.

The main reason for this lack of interest is that the revised law represents a compromise which satisfies noone. The nuclear lobby is unenthusiastic about the restrictions but reckons "it could have been worse". The only positive aspect it discerns is the clarification of the waste disposal problem (5 April). The anti-nuclear group's general attitude is "better than nothing", although one section voted no, on the grounds that if the revision was rejected, a new revision could only be even more restrictive.

The proposals embodied in the revised law contain enough seeds of discontent to ensure that the peace will probably be only a lull in the storm. - The granting of skeleton permits for new nuclear power stations, and of construction permits for those already planned-both to be done now by parliament, rather than the cabinet alone-will depend on:

- the demonstration of electricity demand; and

- safe nuclear waste management.

That the law leaves much latitude in the interpretation of these points became clear at a series of hearings in Bern organised by the Swiss Energy Foundation, the main "soft energy" group and leader of the environmentalist opposition to nuclear development. Officials of the various government de- partments which will be required to put the revised law into practice were interrogated by representatives of both the pro and anti-nuclear groups on their interpretation of the demand and waste management paragraphs, as well as on the proposed procedure for nuclear power stations which already have site but not construction permits.

The transcripts of the hearings ${ }^{1}$ indicate that the "demonstration of demand" will become a hard-fought issue in future. How can demand be demonstrated when Switzerland is literally "throwing away" one-third of all the energy it produces because of inefficient systems, poor insulation, lack of incentives for energy saving, etc.? Is not the level of demand really a political question? What reserve capacity is needed to meet short-term abnormal demands or break-downs in functioning units? To decide these questions it is proposed to set up an Energy Commission, but the problem is how to make sure that it is unbiased and uninfluenced by the powerful lobbies.

\section{Gorleben nuclear waste facility scrapped}

In West Germany last week the premier of Lower Saxony, Herr Ernst Albrecht, announced that he will not grant approval for the building of a nuclear waste reprocessing and disposal facility at Gorleben. Speaking on television he said the decision was not a technical

one-he believed that the plant would be safe--but he had to take account of the weight of public opinion. However, test drilling in salt domes at Gorleben (see below) will continue.

For a detailed review of the decision, see page 283 .

\section{EEC Commissioner opens European nuclear fusion centre}

DR Guido Brunner, member of the European Commission for Energy, Research, Science and Education, laid the foundation stone for JET, the Joint European Torus, at the Culham Laboratory, UK, last week. During the ceremony, Dr Brunner described JET as a "leading project in the world" in the field of fusion research.

JET's world lead, however, has been eroded by the delays to the start of the project caused by the two year negotiations in 1975-77 between EEC member states over where it should be sited. The delay has given its nearest rival, the Tokamak Fusion Test Reactor, at Princeton University, US, an eighteen month lead.

The total cost of building JET is estimated at about 200 million Euro- pean Units of Account (at January 1979 prices). The date for completion is set at the end of 1982 and subsequent annual operating costs are expected to be about $£ 20$ million at today's prices. The JET team, which will be drawn from fusion laboratories all over Europe, is expected to be about 320 strong including 120 scientists and engineers. At present 
130 people are employed on the project, half of them under Euratom contract, and half of them by the UKAEA which runs Culham.

According to Dr Hans-Otto Wüster, Director of the JET Joint Undertaking and Dr Paul Rebut, leader of the JET design team, there are some worries that JET will not attract enough high calibre fusion physicists to make up the rest of the team. One problem is that during the lengthy debate over where to site the project, almost half the design team returned to their home laboratories. Although many of these have now returned to JET, it is feared that the salaries being offered by Euratom are insufficient to entice French and German scientists to the Oxfordshire countryside.

Initially, experiments on JET will be with a D-D plasma. If these are successful, then the project will move into the "radioactive stage" by 198384. This will involve beam-plasma D-T operation resulting in neutron production which will activate the walls of the vessel containing the plasma. Dr Wüster said that this stage of the experimental programme would not commence without further agreement. He also assured that the radioactivity produced would be between ten and a hundred times less than that produced by nuclear fission. As the amount of radioactive material created would be very small, he thought that energy produced from fusion could prove "environmentally advantageous".

The decision over whether or not to enter the 'radioactive stage' is bound to be difficult, according to $\mathrm{Dr}$ R. J. Bickerton. There is already one school of thought which would like to proceed to reactor conditions as quickly as possible and another that would rather understand the plasma physics thoroughly first. This difference in opinion is to some extent reflected in the discussions which have already started on the machine to follow JET. Dr Bas Pease, Director of Culham Laboratory, thinks that the next machine should aim at demonstrating a net production of electricity. "I favour the view that we should attempt this after JET, but I can't yet say that I have persuaded a majority of colleagues of that view", he said.

The Euratom countries have already set up a Next European Torus Study Group to discuss the next machine. According to Dr Brunner, however, Europe may not be able to afford to build JET's successor alone. It is therefore cooperating in the INTOR Study Group, under the auspices of the International Atomic Energy Agency, which is looking at the possibility of the USSR, Western Europe, the US and Japan building a worldwide machine.

Judy Redfearn

\section{US foreign research rises to $\$ 1 \cdot 5$ billion}

THE vast majority of research carried out by US private corporations in foreign countries is concerned with developing products for local market conditions, rather than with longer term basic or applied research goals, according to a survey conducted by the National Science Foundation.

Research and development carried out abroad by US corporations increased by $41 \%$ between 1974 and 1977 , to a total of $\$ 1.5$ billion, the survey reports. This represents about $7 \%$ of the total expenditure on R\&D by private companies, which increased by $32 \%$ over this period.

The most substantial increase in overseas R\&D occurred in the pharmaceutical industry, with many companies conducting trials of new drugs abroad in order to take advantage of more liberal conditions on foreign testing introduced by the Food and Drug Administration in 1975. Thus between 1974 and 1977, the amount of R\&D conducted by pharmaceutical companies abroad more than doubled, compared to an increase of only $34 \%$ in the funds spent at home over this period (although the report adds that foreign and domestic $R \& D$ are now increasing at about the same rate).

The NSF survey says that in companies with world-wide research capabilities, the US laboratory usually takes the lead in overall technological development, with the foreign labora-

\section{University of Houston expels professor}

THE University of Houston in Texas is refusing to renew the contract of Professor Archer J. P. Martin, joint winner of the Nobel prize for chemistry in 1952 with R. L. M. Synge for his work on chromatography, on the grounds of "inadequate productivity".

Professor Martin, who is 69, was appointed to the Welch chair of chemistry in 1974, and until last year held a joint appointment at the University of Sussex, where he was carrying out research on protein separation sponsored by the Medical Research Council.

The University of Houston requires that after a faculty member reaches the age of 64 , his or her tenure must be renewed annually. Last year the university told Dr Martin that the Department of Chemistry did not consider he had published enough scientific papers, and that his appointment would not be renewed.

Professor Martin told Nature last week that when he took the post, he had not been aware that there would be little money for research assistants or experimental facilities and consequently that he spent most of his time in Houston planning experiments to be carried out in Sussex. tories providing specialised development for particular market conditions. The foreign R\&D facilities of these companies therefore conducted primarily development projects, even though basic and applied research accounts for almost one quarter of total domestic R\&D spending by US companies.

Interviews carried out with the managers of 18 large private corporations revealed only one case in which a company reported any expenditure on basic research conducted outside the US. Two other companies reported that their foreign research facilities carried out some applied research work.

Looking to the future, the NSF study says that an expected increase in overseas sales by US corporations is likely to cause such companies to open new foreign R\&D facilities or to expand existing operations, with increased sales, rather than other factors such as lower research and development costs, providing the main motivation for such developments.

The report also notes that several R\&D directors outside the pharmaceutical industry said that increasing regulation by bodies such as the Occupational Safety and Health Administration and the Environmental Protection Agency in the US would tend to cause companies to move $R \& D$ resources to other countries wher operations would not be affected as much.

$\mathrm{He}$ accepts that he has published very few scientific papers over the past five years from his work at Houston, but claims that he has no desire to rush into print unnecessarily (his total scientific output is about 70 soientific papers). According to Professor Martin, the university did not take into account papers produced from the work at Sussex in considering whether his contract should be renewed.

A faculty committee, to which Professor Martin protested at his dismissal, came to the conclusion that the terms of his appointment had not been initially made adequately clear, and recommended that he be kept on the staff. However, two weeks ago Professor Robert H. Walker, Dean of the College of Natural Sciences and Mathematics, informed Professor Martin that the university had no power to keep him on unless the Department of Chemistry changed its mind. According to Dr. Walker, the university does not set any specific target on the number of papers which a research worker is expected to produce each year but, he says that there is nevertheless "a certain expectation of productivity". 